\title{
PENGARUH CLAPPING, VIBRASI DAN SUCTION TERHADAP TIDAL VOLUME PADA PASIEN PNEUMONIA YANG MENGGUNAKAN VENTILATOR DI RUANG ICU ROYAL PRIMA MEDAN
}

\section{Effect of Clapping, Vibration and Suction Against Tidal Volume of Pneumonia Patients Using Ventilator in ICU Room of Royal Prima Hospital Medan}

\author{
Agnesia Vaulina', Yana Malinda ${ }^{2}$, Yunistia Gulo ${ }^{3}$, \\ Victory Oktavianus ${ }^{4}$, Tiarnida Nababan ${ }^{5}$ \\ 1,2,3,4 Mahasiswa S1 Keperawatan, FKK Universitas Prima Indonesia Medan \\ Email : agnesiavaulina@gmail.com ${ }^{1}$, yanamalinda07@ gmail.com $^{2}$, \\ yunistialuese1998@ gmail.com ${ }^{3}$, viccowand2@ gmail.com ${ }^{4}$ \\ ${ }^{5}$ Dosen Tetap FKK Universitas Prima Indonesia Medan \\ Email : tiarnidan@yahoo.com
}

DOI : https://doi.org/10.34008/jurhesti.v4i1.92

\begin{abstract}
Abstrak
Melihat dampak yang bisa terjadi pada pasien yang menggunakan ventilator dan kemampuan pasien untuk mengeluarkan sekret sangat terbatas, maka sangat perlu sekali membantu pasien dalam menjaga kebersihan jalan napasnya, sehingga pernapasan berjalan lancar. Salah satu upaya yang dapat dilaksanakan yaitu melakukan clapping, vibrasi dan suction sesuai dengan standar operasional prosedur. Tujuan penelitian ini adalah untuk mengidentifikasi pengaruh clapping, vibrasi dan suction terhadap tidal volume pada pasien pneumonia yang menggunakan ventilator di ruang ICU Rumah Sakit Royal Prima Medan. Desain penelitian ini menggunakan metode quasi eksperimen. Sampel pada penelitian ini sebanyak 10 orang berdasarkan total populasi selama 2 minggu dari tanggal 1 sampai 15 Juli 2019 dengan teknik total sampling. Instrumen yang digunakan adalah lembar observasi pada pasien pneumonia yang menggunakan ventilator. Uji yang digunakan dalam penelitian ini adalah uji T-dependen untuk melihat adanya pengaruh clapping, vibrasi dan suction terhadap tidal volume dengan nilai signifikan $(\mathrm{p}<0,05)$. Saran penelitian ini adalah diharapkan kepada pihak rumah sakit khususnya petugas kesehatan lebih memperhatikan kebersihan jalan napas dengan melakukan tindakan claping, vibrasi dan suction khususnya pada pasien yang terdiagnosa pneumonia yang sedang dirawat menggunakan ventilator.
\end{abstract}

Kata kunci : clapping, vibrasi, suction, tidal volume, pneumonia.

\begin{abstract}
See the impact that can occur in patients who use ventilators and the ability of patients to issue very limited secretions, it is very necessary to help the patient in maintaining the hygiene of the road, so that the breathing runs smoothly. One of the efforts that can be done is clapping, vibration and suction in accordance with the operational standards of Prosdur. The purpose of this research is to identify the influence of clapping, vibration and suction against tidal volumes in pneumonia patients who use a ventilator in the ICU room of Royal Prima Medan Hospital. The design of this research uses the experimental quasi method. Samples on this study were as much as 10 people based on the total population during 2 weeks from 1st to 15 th July 2019 with total sampling technique. The instrument used is an observation sheet in a ventilator-using pneumonia patient. The test used in this study is the TDependen test to see the influence of clapping, vibration and suction against tidal volumes with significant value $(\mathrm{P}<0.05)$. The advice of this research is to be expected to the hospital, especially health workers pay attention to the hygiene of the airway by doing the action of claping, vibration and suction especially in patients who are diagnosed with pneumonia are treated with ventilators.
\end{abstract}

Keywords: clapping, vibration, suction, tidal volume, pneumonia

\section{PENDAHULUAN}

Pneumonia adalah inflamasi parenkim paru yang disebabkan oleh berbagai mikroorganisme termasuk bakteri, mikrobakteria, jamur dan virus (Brunner \& Suddarth, 2013). Data World Health
Organization (2016), penyebab kematian tertinggi akibat penyakit infeksi di dunia adalah infeksi saluran napas bawah termasuk pneumonia. Menyebabkan 3 juta kematian di seluruh dunia pada tahun 2016. Hal ini menyebabkan pneumonia menempati urutan 
ke empat penyebab kematian di dunia (World Health Organization, 2018).

Dari hasil pemetaan yang dilakukan Riset Kesehatan Dasar (Riskesdas) tahun 2018, angka kejadian pneumonia di Indonesia mengalami peningkatan menjadi $2,0 \%$, provinsi dengan angka kejadian pneumonia yang tinggi antara lain:

Papua(3,6\%), disusul oleh provinsi Bengkulu(3,4\%), Papua Barat $(2,9 \%)$ dan diikuti oleh provinsi lain di seluruh Indonesia, sedangkan di provinsi Sumatra Utara sebesar(2,1\%) oleh karena itu pneumonia perlu mendapat perhatian (RISKESDAS, 2018).

Menurut Hendra (2011), tindakan clapping, vibrasi dan suction atau fisioterapi dada sangat berguna bagi penderita penyakit paru dalam mengembalikan dan memelihara fungsi otot-otot pernafasan dan membantu membersihkan sekret dari bronchus dan untuk mencegah penumpukan sekret. Tindakan clapping, vibrasi dan suction atau fisioterapi dada ini dapat digunakan untuk pengobatan dan pencegahan pada penyakit

paru obstruktif menahun, penyakit pernafasan retriktif karena kelainan

parenkim paru dan pasien yang menggunakan ventilasi mekanik.

Tindakan clapping, vibrasi dan suction sangat bermanfaat bagi penderita paru baik yang akut maupun kronis, tindakan clapping, vibrasi dan suction memiliki tujuan untuk meningkatkan faal

paru dan untuk melapangkan jalan pernapasan. Fungsi utama dari tindakan clapping, vibrasi dan suction memiliki fungsi utama untuk mempertahankan fungsi utama respirasi serta membersihkan saluran pernafasan dari sekret (Rab, 2010).

Volume tidal adalah volume udara yang di inspirasi atau ekspirasi pada setiap kali pernapasan normal. Besarnya $\pm 500 \mathrm{cc}$ pada rata-rata orang dewasa (A. Rifa'I, dkk, 2013). Tindakan clapping, vibrasi dan suction untuk itu diharapkan mampu mengatasi kebersihan jalan napas dan kebutuhan oksigenasi dan pengembangan paru tercapai pada pasien pneumonia yang menggunakan ventilator dengan gambaran hasil tidal volume.

\section{METODE}

Penelitian ini dilakukan di ruang ICU Rumah Sakit Royal Prima Medan, penelitian ini dilaksanakan tanggal 1 Juni 15 Juni 2019. Desain penelitian yang digunakan dalam penelitian ini adalah quasi eksperimen atau eksperimen semu.

Populasi dalam penelitian ini adalah semua pasien pneumonia yang menggunakan ventilator, Pengambilan sampel dengan metode non probability sampling dengan teknik sampling yang digunakan adalah teknik total sampling, yaitu pengambilan sampel dimana jumlah sampel sama dengan populasi. Pada penelitian ini objek yang akan diteliti yaitu pasien pneumonia yang menggunakan ventilator. Sampel yang diambil dalam penelitian ini adalah 12 orang.

Alat pengumpulan data yaitu lembar observasi tujuan utama dari lembar observasi adalah mencatat fenomena yang muncul dan dari hasil pencatatan inilah yang akan membantu untuk menarik kesimpulan dan membantu menemukan solusi yang dibutuhkan. Lembar observasi terdiri dari identitas umum responden dan tabel penilaian pretest dan post-test terhadap tindakan clapping, vibrasi dan suction yang dilakukan. Tahapan dalam penelitian ini, semua data- data awal mengenai tidal volume pasien dikumpulkan melalui pretest, nilai dari hasil pengukuran menggunakan alat spirometer wright yang sudah di lekatkan pada selang ventilator. Selanjutnya responden akan diberikan tindakan clapping, vibrasi dan suction. Setelah diberikan tindakan, data akhir penelitian ini dikumpulkan melalui post-test.

Teknik pengolahan data dalam penelitian ini terdiri dari editing, coding, entry dan cleaning. Sedangkan analisis data yang dilakukan adalah analisis univariat dan analisis bivariat dengan uji statistik $\mathrm{T}$ Dependen dengan nilai signifikannya $(p<0,05)$ dengan mengunakan uji statistik TDependen SPSS.

\section{HASIL DAN PEMBAHASAN}
Tabel 1. Distribusi Frekuensi Karakteristik Responden Berdasarkan Jenis Kelamin dan Usia Responden Di Ruang ICU Royal Prima Medan (n=12) 


\begin{tabular}{|c|c|c|}
\hline $\begin{array}{c}\text { Karakteristik } \\
\text { Responden }\end{array}$ & Jumlah (n) & $\begin{array}{c}\text { Persentase } \\
(\%)\end{array}$ \\
\hline \multicolumn{3}{|l|}{ Jenis Kelamin } \\
\hline a. Laki-laki & 9 & 75 \\
\hline b. Perempuan & 3 & 25 \\
\hline Total & 12 & 100 \\
\hline \multicolumn{3}{|l|}{ Usia } \\
\hline a. $50-60$ & 5 & 41.7 \\
\hline b. $61-70$ & 4 & 33.3 \\
\hline c. $71-80$ & 3 & 25 \\
\hline Total & 12 & 100 \\
\hline
\end{tabular}

Berdasarkan tabel di atas diketahui bahwa dari 12 orang responden mayoritas berjenis kelamin laki-laki sebanyak 9 orang $(75,0 \%)$ dan minoritas berjenis kelamin perempuan sebanyak 3 orang $(25,0 \%)$. Dari 12 orang responden mayoritas umur 50-60 tahun sebanyak 5 orang $(41,7 \%)$, minoritas berusia 71-80 tahun sebanyak 3 orang $(25,0 \%)$, dan usia 61-70 tahun sebanyak 4 orang $(33,3 \%)$.

Tabel 2 Distribusi Frekuensi Responden Sebelum Dilakukan Tindakan Clapping, Vibrasi Dan Suction Terhadap Tidal Volume Pada Pasien Pneumonia Yang Menggunakan Ventilator Di Ruang ICU Royal Prima Medan (n=12)

\begin{tabular}{ccc}
\hline Tidal Volume & Jumlah (n) & $\begin{array}{c}\text { Persentase } \\
(\boldsymbol{\%})\end{array}$ \\
\hline a. $100-300$ & 6 & 50.0 \\
b. 400-600 & 6 & 50.0 \\
Total & 12 & 100 \\
\hline Sumber: Data Primer 2019
\end{tabular}

Berdasarkan tabel diatas didapatkan bahwa tidal volume pasien sebelum di berikan Clapping, Vibrasi dan Suction didapat dari 12 orang responden sebanyak 6 orang (50\%) yang tidal volumenya 100-300 $\mathrm{ml}$ dan sebanyak 6 orang $(50 \%)$ yang tidal volumenya $400-600 \mathrm{ml}$.

Tabel 3 Distribusi Frekuensi Responden sesudah dilakukan Clapping, Vibrasi dan Suction Terhadap Tidal Volume Pada Pasien Pneumonia Yang Menggunakan Ventilator Di Ruang ICU Royal Prima Medan ( $n=12)$

\begin{tabular}{ccc}
\hline Tidal Volume & Jumlah $(\mathrm{n})$ & Persentase $(\%)$ \\
\hline a. $100-300$ & 2 & 16.7 \\
b. $400-600$ & 10 & 83.3 \\
\hline Total & 12 & 100.0 \\
\hline Sumber : Data Primer 2019 &
\end{tabular}

Berdasarkan tabel di atas didapatkan bahwa tidal volume sesudah diberikan Clapping, Vibrasi dan Suction dari 12 orang responden yang mengalami perubahan tidal volume sebanyak 10 orang $(83,3 \%)$ yang tidal volumenya $400-600 \mathrm{ml}$ dan sebanyak 2 orang $(16,7 \%)$ tidal volumenya $100-300 \mathrm{ml}$. data ini menunjukkan mayoritas responden mengalami peningkatan pada tidal volume, minoritas responden tidak mengalami peningkatan tidal volume.

Tabel 4. Uji normalitas shapiro wilk data responden di Royal Prima Medan (n=12)

\begin{tabular}{|c|c|}
\hline & Tidal Volume Tidal Volume \\
\hline & (pretest) $\quad$ (Post test ) \\
\hline Shapiro-wilk & 0,962 \\
\hline P-value & 0,095 \\
\hline
\end{tabular}

Berdasarkan tabel di atas diketahui bahwa nilai dari uji normalitas Shapiro wilk pada tidal volume(pretest) dengan nilai $\mathrm{p}=0,095$ dan kualitas hidup (post test) adalah 0,818 . Hal ini berarti nilai uji normalitas >0,05 yang artinya data diatas berdistribusi normal.

Tabel 5. Pengaruh Clapping, Vibrasi Dan Suction Terhadap Tidal Volume Pada Pasien Pneumonia Yang Menggunakan Ventilator Di Ruang ICU Rumah Sakit Royal Prima Medan Tahun 2019 (n=12)

Paired Samples Test

\begin{tabular}{crrr} 
Paired Samples Test & \\
\hline $\begin{array}{c}\text { Std. Std. } \\
\text { Mean deviation error }\end{array}$ & $T$ Df $\begin{array}{r}\text { (2- } \\
\text { tailed) }\end{array}$ \\
\hline
\end{tabular}

Pre

test

dan-65.917 $\quad 88.27325 .482-2.587 \quad 11 \quad .025$ post

test

Sumber : Data Primer 2019

Berdasarkan hasil tabel 5 di atas didapatkan bahwa jika nilai signifikasi > 0,05 maka Ho diterima san Ha di tolak. Jika 
nilai signifikasi < 0,05 maka Ho di tolak dan Ha diterima.Berdasarkan hasil perhitungan uji T-Dependen atau Paired Samples Test di peroleh nilai $\mathrm{t}$ sebesar -2.587 dengan $(\mathrm{p}=$ $0,025)$ atau $<0,05$ sehingga keputusan hipotesis Ho di tolak. Artinya ada pengaruh yang signifikan yaitu pengaruh clapping, vibrasi dan suction terhadap tidal volume pada pasien pneumonia yang menggunakan ventilator di ruang ICU Rumah Sakit Royal Prima Medan Tahun 2019.

Hasil penelitian ini menunjukkan bahwa terdapat pengaruh clapping, vibrasi dan suction terhadap tidal volume pada pasien pneumonia yang menggunakan ventilator berdasarkan analisis statistik

bivariat didapatkan nilai signifikasi $(\mathrm{p}=0,025)$ nilai ini lebih kecil dari nilai signifikasi $(\mathrm{p}=0,05)$, ini berarti terdapat pengaruh yang signifikan antara variabel clapping, vibrasi dan suction dengan variabel tidal volume. Artinya bahwa penyataan hipotesis adanya pengaruh clapping, vibrasi dan suction terhadap tidal volume pada pasien pneumonia yang menggunakan ventilator dapat diterima.

Hasil penelitian ini sesuai dengan penelitian yang dilakukan oleh Siti Maimuna, dkk (2014) tentang efektivitas clapping dan vibrating terhadap kebersihan jalan napas klien dengan ventilasi mekanik dengan gambaran hasil saturasi oksigen. analisis menggunakan Paired t test yang dilakukan terhadap saturasi oksigen pada kelompok perlakuan didapatkan $\mathrm{p}=0,00$ yang artinya ada pengaruh clapping dan vibrating terhadap saturasi oksigen sebelum dan sesudah dilakukan perlakuan. Pada kelompok kontrol didapatkan nilai $\mathrm{p}=0,078$ yang artinya tidak ada pengaruh clapping dan vibrating terhadap saturasi oksigen sebelum dan sesudah dilakukan perlakuan. Sedangkan hasil analisis $T$ test independent pada saturasi oksigen terhadap kelompok perlakuan dan kelompok kontrol didapatkan nilai $\mathrm{p}=0,00$ yang berarti ada perbedaan antara kelompok perlakuan terhadap kelompok kontrol terhadap tindakan clapping dan vibrating.

Hasil penelitian Saifuddin, dkk (2018) analisis menggunakan uji Wilcoxon yang dilakukan terhadap saturasi perifer oksigen pada kelompok kontrol dan kelompok peralakuan didapatkan nilai $\mathrm{p}$ value $=0,004(p<0,05)$ maka hipotesis kerja pada penelitian ini diterima, yang menunjukkan adanya perbedaan kadar saturasi oksigen sebelum dan sesudah di berikan tindakan penghisapan lendir.

Penelitian ini menunjukkan bahwa tindakan clapping, vibrasi dan suction merupakan tindakan yang harus di perhatikan dan penting untuk dilakukan oleh perawat khususnya perawat ICU. Pentingnya tindakan clapping, vibrasi dan suction ini dilakukan untuk melihat keadaan pasien yang sedang dirawat di ruang ICU terutama pada pasien pneumonia yang menggunakan ventilator dengan gambaran tidal volume pasien normal. Tindakan ini dapat mencegah terjadinya penumpukan sekret yang dapat menyebabkan kegagalan napas sehingga pasien dapat meningkatkan kualitas hidupnya.

KESIMPULAN DAN SARAN Kesimpulan dari penelitian ini

adalah terdapat pengaruh tindakan clapping, vibrasi dan suction terhadap tidal volume pada pasien pneumonia yang menggunakan ventilator di ruang ICU Rumah Sakit Royal Prima Medan.

Saran bagi tenaga kesehatan mampu menerapkan tindakan clapping, vibrasi dan suction sehingga dapat mencegah kegagalan napas pada pasien pneumonia terutama yang menggunakan ventilator.

\section{DAFTAR PUSTAKA}

Brunner, \& Suddarth. 2002. Keperawatan Medikal Bedah. Jakarta: EGC.

Brunner, \& Suddarth. 2013. Keperawatan Medikal Bedah Edisi 12 . Jakarta : EGC.

Djojodibroto, D. 2009. Respirologi (Respiratory Medicine). Jakarta: EGC.

Hendra, \& Huriani, E. 2011. Pengaruh Mobilisasi dan Fisioterapi Dada

Terhadap Kejadian Ventilator Associated Pneumonia di Unit Perawatan Intensif. Ners Jurnal Keperawatan , 7 (2), 121-129.

Maimuna, S., Supriyanto, D., \& Bahrudin, M. 2014. Efektifitas Clapping dan Vibrating Terhadap Kebersihan Jalan 
Nafas Klien Dengan Ventilasi

Mekanik. Jurnal Keperawatan , 7 (2).

Nizar, A. M., \& Haryati, D. S. 2017.

Pengaruh Suction Terhadap Kadar

Saturasi Oksigen Pada Pasien Koma

Di Ruang ICU RSUD Dr. Moewardi

Surakarta Taun 2016. Jurnal

Keperawatan Global , 2 (2), 62-111.

Notoadmodjo, P. S. 2012. Metodologi

Penelitian Kesehatan. Jakarta: Rineka

Cipta.

Rab, P. D. 2010. Ilmu Penyakit Paru.

Jakarta: Trans Info Media .

Rifa'i, A., Edi, S. S., \& Sunaro. 2013.

Aplikasi Sensor Tekanan Gas

MPX5100 Dalam Alat Ukur Vital

Paru-Paru. Unnes Physics Journal, 2

(1).
RISKESDAS. 2018. Diambil kembali dari www.depkes.go.id.

World Health Organization. 2018. Diambil kembali dari Global Health Estimates 2016 Death Cause , Age, Sex, by Country and by Region,2000-2016.

Zukhri, S., Suciana, F., \& Herianto, A. 2018. Pengaruh Isap Lendir (suction) Sistem Terbuka Terhadap Saturasi Oksigen Pada Pasien Terpasang Ventilator. Motorik, 13 (26). 